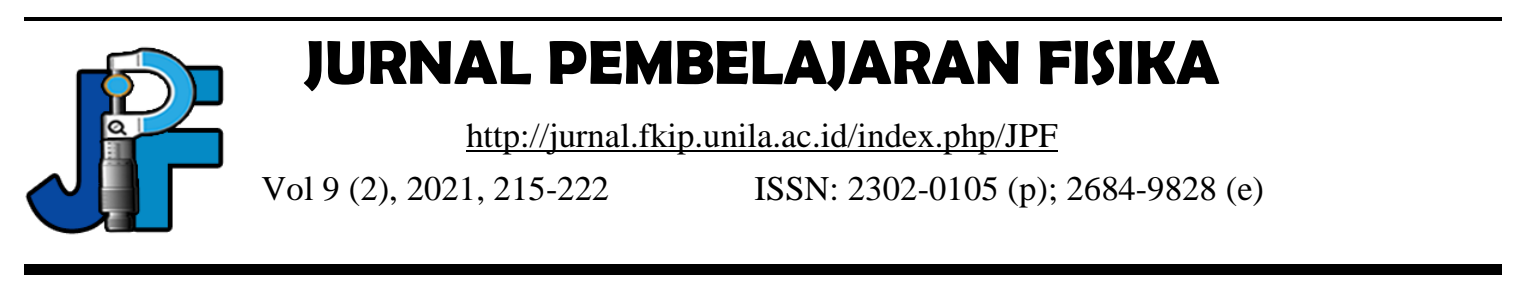

\title{
Implementation of Conceptual Change of Gas Kinetic Theory Material using Process Images
}

\author{
Indro Wicaksono ${ }^{1 *}$, Linda Kurnia Supraptiningsih ${ }^{1}$, Haritsah Alfad ${ }^{2}$ \\ ${ }^{1}$ Panca Marga University, Indonesia \\ ${ }^{2}$ Akademi Farmasi Putera Indonesia Malang, Indonesia \\ *e-mail: indrowicaksono@upm.ac.id
}

Received: November 15, 2021

Accepted: December 30, 2021

Published: December 31, 2021

\begin{abstract}
The aim of this research is to implement the learning of conceptual changes in kinetic gas theory material using process drawings. This research is a pre-experimental with one-group pretest-posttest design for 30 students of XI IPA 7 MAN 2 Probolinggo City. The instrument used is a description test of 6 questions. The results of the data analysis showed that the change in student concept after using process images in kinetic gas theory material increased with an average increase score of 0.51 (medium gain). This happens because students still experience misconceptions on the material laws of gas that are associated with the phenomena of daily life and the effective speed of gases theoretically.
\end{abstract}

Keywords: conceptual change; gas kinetic theory; and process images

DOI: http://dx.doi.org/10.23960/jpf.v9.n2.202108 


\section{INTRODUCTION}

One of the physics materials that must be studied in schools based on the 2013 curriculum is gas kinetic theory material. This gas kinetic theory material is a physical material that studies the laws of gas and the properties of ideal gases in enclosed spaces. The material of this gas kinetic theory can be studied in 2 circumstances, namely concretely and abstractly. Material can be concretely practiced or proven in real time, so that the concept of physics can be understood more easily. this is in accordance with research conducted by Hernawati (2018) which stated that the application of demonstration methods and audiovisual media can improve students' physics learning outcomes in grade $\mathrm{X}$. Meanwhile, in abstract materials there needs to be a concept theme to help students understand. This is in accordance with research conducted by Hanna, D., Sutarto, \&Harijanto, A (2016) stated that the results of learning using concept theme learning models are better than the learning models commonly used in schools.

Research related to the material of gas kinetic theory is research conducted by Yaumi, M., Sutopo, Zulaikah, S (2019) that students have mastered the concept on the material of gas kinetic theory, but the concept on the relationship between pressure and volume, internal energy, and the average speed of ideal gas is still experiencing some difficulties. In addition, students still have difficulty with mathematical calculations. Other research conducted by Agustina, M., Yushardi, \&Djoko Lesmono, A (2018) resulted in that the percentage of concept mastery based on mastery indicators on $\mathrm{C} 4$ (analysis) with low category, C5 (evaluation) with enough category, C6 (creating) with very low category. Another study that uses learning media in studying the material of gas kinetic theory is research conducted by Putra, A. P., Rochman, C., \& Setya, W (2020) which results in the use of virtual laboratory PhET has a moderate effectiveness to improve the mastery of concept mastery concepts in gas kinetic theory material.

Based on the results of the above research, it can be known that in studying the concept of physics in the material of gas kinetic theory, there needs to be a proper medium to help change the concept of students. This precise medium shows that it can be used by all students and makes it easier for students to understand the concept of physics. In addition to being virtual in electronic form, the right media to be used by students is the process image print media. Print media images of this process can be a student worksheet equipped with process images that are a series of images of objects (objects, events, or phenomena that are real or abstract, which can be seen or can only be imagined) that the images in the series between the images with each other always appear there is relative difference in terms (circumstances, positions, shapes, and its combination) which overall describes a stage of complete unity and unity (Sutarto et al, 2018). With the process images will help students in distinguishing images from each other, so understanding the concept of physics will be easier for students to obtain.

Related to the print media image process on physics learning, Wicaksono, I., Sutarto, \& Marzuki, I (2019) has developed a student activity sheet based on printed media image process using computer and technology (CAT) on kinematics materials. The results of the study produced the feasibility of student activity sheets to measure students' critical thinking. The research shows that process images have an impact on learners' thinking abilities. However, in this study the process images implemented can 
affect conceptual changes for high school students. Conceptual changes for high school students in learning Physics materials are indispensable. This can reduce the presence of misconceptions in Physics materials. The conceptual change of the process image arises from the stimulus in the form of an image of a complete and complete stage. Therefore, research on concept changes using process images needs to be done on physics learning.

Based on the description above, shows that the process image can be a solution to study the material kinetic gas theory. Kinetic gas theory material that is concrete or abstract can be presented in the form of an image of a complete and complete stage. Thus, the image of the process can facilitate students in exploring the magnitude of physics that affect each other. Concrete material on the kinetic gas theory is gas laws which include Boyle's law, Charles's law, Lussac's Gay law, and Lussac's Gay Boyle's Law were given at the first meeting. While the abstract material is from the general equation of ideal gas, kinetic energy average gas idel, and effective speed is given at the second meeting. In addition, other abstract materials such as energy and energy parties were given at the third meeting. With proper conceptual fruiting, it will certainly reduce misconceptions.

\section{METHOD}

\section{Research Design \& Procedures}

This research is a pre-experimental with one-group pretest-posttest design. Researcher provide pretest then gives treatment deliberately and systematically to a group that is in the form of learning treatment through the conceptual change learning with process image, and at the end of learning is given postest.

\section{Population and Sample}

Research population is students of grade XI IPA even semester 2020/2021 school yearstudent of MAN 2 Kota Probolinggo . Samples were taken using purposive sampling method. The sample is class XI IPA 7 with 30 students.

\section{Data Collection and Instrument}

Data collected in this research is conceptual change through understanding concepts based on process images. Research instruments used in this research is a test of the description of gas kinetic theory material that has been tested by experts.

\section{Data Analysis}

Data analysis is done by grouping student answer results based on similar explanations. Thus there appears to be conceptual changes due to learning using process images. Then, this study is also equipped with interviews for students who have different answers 


\section{RESULT AND DISCUSSION}

Analysis of answers from 30 students of MAN 2 Kota Probolinggo class XI IPA 7 to 6 questions of description to measure conceptual changes in the kinetic theory material of gases conducted by pretest and postest after learning using process images. The purpose of pretset and posttest is to observe the conceptual changes of students using the $\mathrm{N}$-gain formula. The average yield of an $\mathrm{N}$-gain score is 0.51 (medium gain). Here is a table of average $\mathrm{N}$-gain results from 30 students as respondents:

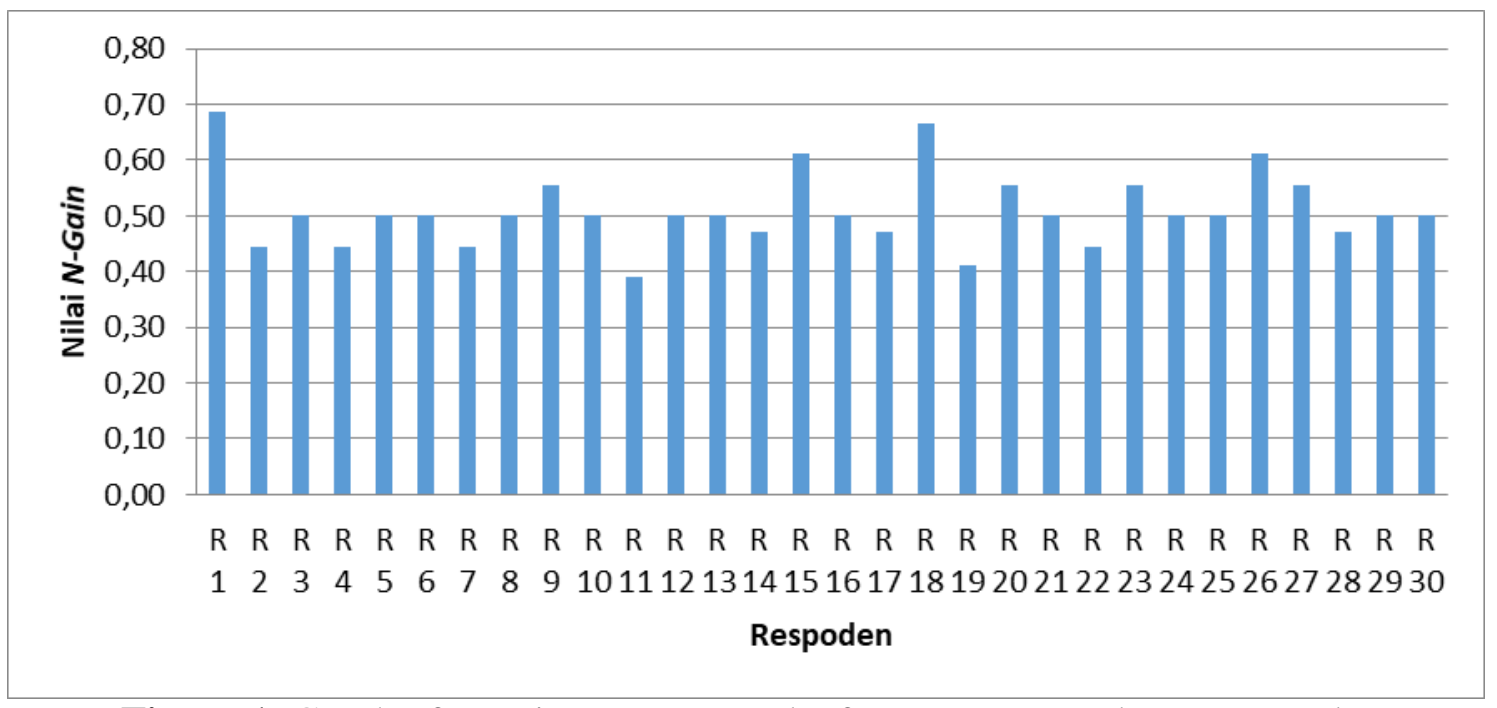

Figure 1. Graph of N-gain average results from prestest and postest results

There is a difficulty that is ignored by this student because of the misconception of the analysis of gas laws in the numbers 1 and 3, as well as the effective speed of gas and energy in the gas contained in the number 2 and 5 problem points as follows.

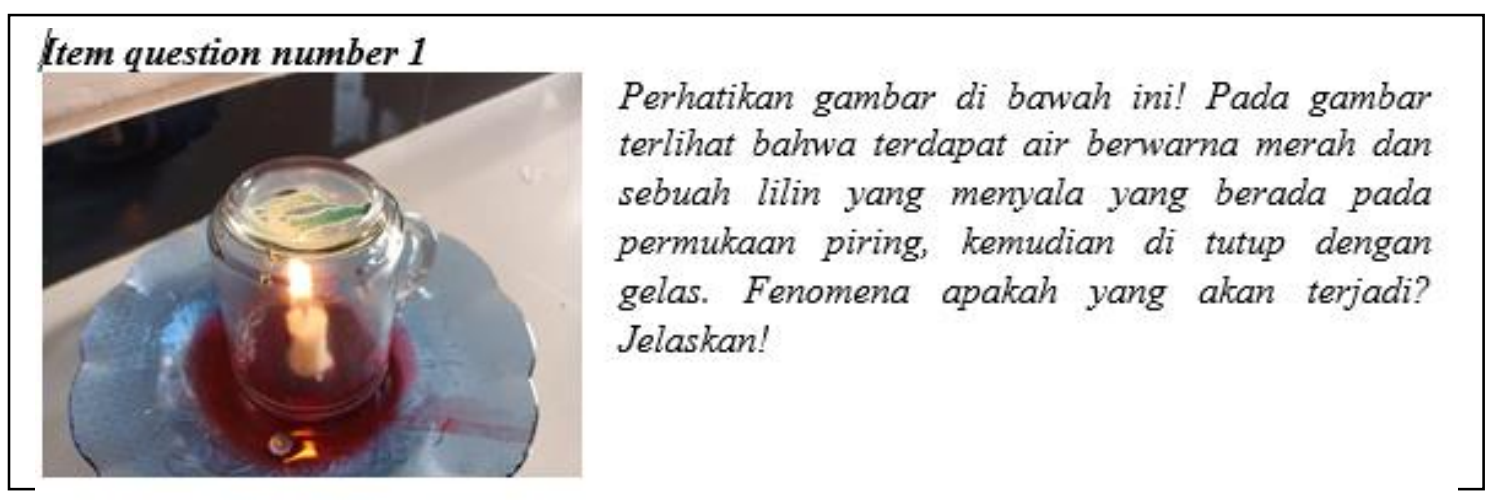

In the above question, there are only 2 students who have achieved a change in concept that is to review the amount of temperature with pressure, if the temperature is lower then the pressure will also be lower. This happens because of the temperature with the pressure. Based on the picture above, if the fire on the lilies has been extinguished, then the temperature in the room will be low because the oxygen needed to burn the candle has been exhausted, then the greatest pressure is outside the glass, as a result of the fluid 
in the form of water that is outside the glass will be pressured to enter the closed glass room. While the answer from the other 28 students experienced a misconception that assumes that the cause of the movement of water into the glass because the pressure is inversely proportional to the volume, not to the temperature and pressure.

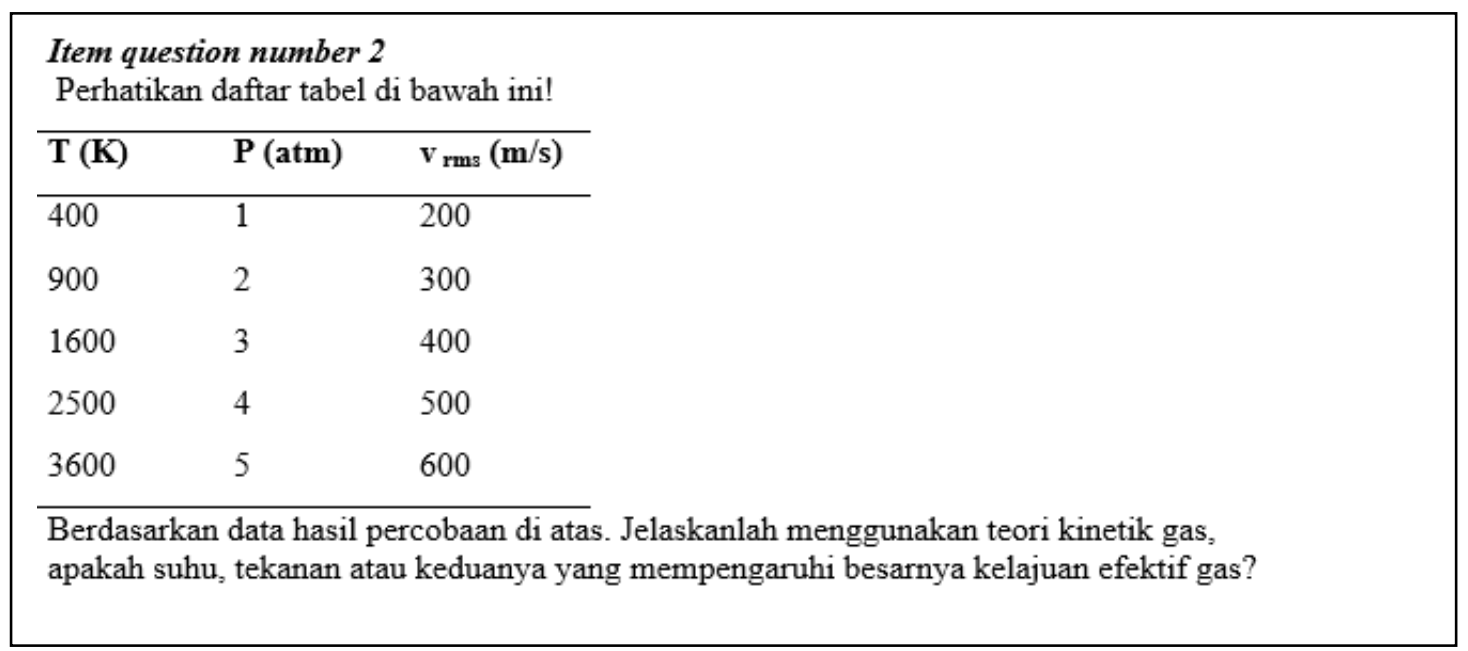

In this question 30 students have undergone a change in concept, which originally when pretest there were only answered "yes" or "Could Be" or dicosongi. After carrying out the kinetic theory of gas material learning using process drawings, many students answer based on the effective speed formula:

$$
v_{r m s}=\sqrt{\frac{3 k T}{m}}=\sqrt{\frac{3 R T}{M_{r}}}=\sqrt{\frac{3 P}{\rho}}
$$

Thus appears the answer "effective speed is proportional to the root of temperature and speed". This leads to misconspection. Supposedly, pressure does not affect the effective speed of the gas although there are the following formulas:

$$
v_{r m s}=\sqrt{\frac{3 P}{\rho}}
$$

For the pressure of the gas to get bigger indicates that the volume is getting smaller and the mass of the type $\rho$ will be greater. Thus the ratio of pressure P and mass of type $\rho$ is fixed, and will not affect the effective velocity of the gas. The student's answer will be more accurate if the effective speed is proportional to the root temperature of the gas and due to the faster motion of gas particles will pound the walls of closed spaces more often, so that the pressure that occurs in large closed spaces.

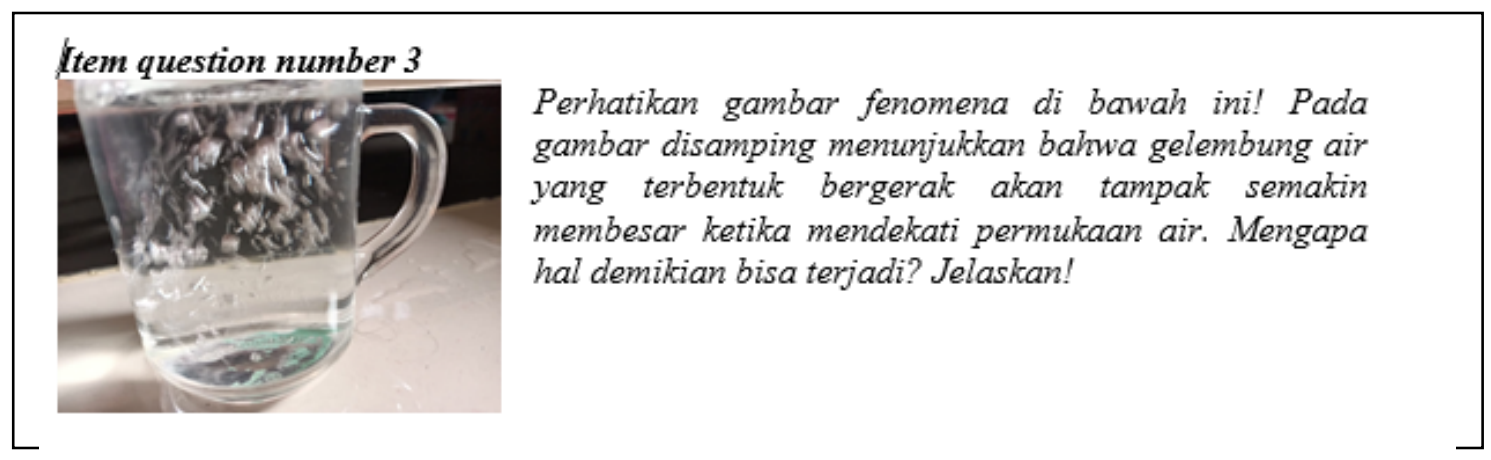


Based on the above question, there are 11 students who have been able to change their concept with the right answer. The student explained that the closer the surface of the gas pressure will be smaller because the hydrosactic pressure is getting smaller, so the gas bubble will enlarge. This is in accordance with Boyle's law, that as much as the pressure of the gas, the volume will be smaller when it is in an enclosed space. The other 19 students still had misconceptions, which assume that the pressure will get closer to the surface and cause the volume of gas to get bigger.

\section{Item question number 4}

Pada malam hari di suatu pemukiman penduduk telah terjadi peristiwa kebakaran oleh salah satu rumah warga. Peristiwa tersebut memicu ikut terbakarnya rumah penduduk yang lainnya, sehingga api semakin membesar dan mudah merambat menghabiskan rumah penduduk. Mengapa hal ini bisa terjadi?

Of those questions, only 1 student out of 30 answered because of its flammable media. Meanwhile, other students showed a change in concept, namely if the gas temperature is increasingly high then the speed of gas will be faster. This results in greater wind speeds, making it easy to propagate and burn other houses.

\section{Item question number 5}

Pada jalan tol selalu disediakan tempat Rest Area. Tempat tersebut digunakan untuk tempat beristirahat dan menjaga keadaan ban mobil agar tidak meletus ketika siang hari yang amat panas. Jelaskanlah mengapa ban mobil bisa meletus ketika siang hari yang amat panas di jalan tol!

In this question there are also many students who answer differently with the concept they developed themselves. There are students who answer that because of the high temperature so the tire had peeled off, while the pressure inside the tire is getting bigger akibtnya tire erupts. There are also students who answer that cars do not utilize rest areas to reduce the pressure of large gases due to hot weather temperatures. The student's answer would be more precise when associated with energy in gas, namely The increase in temperature will increase the average kinetic energy of gas in car tires because it $E_{K}=\frac{3}{2} k T$ or $E_{K} \sim T$. As a result the energy in the gas will increase because the $\Delta U=\frac{3}{2} N k \Delta T$ or $\Delta U \sim \Delta T$ so that the pressure in the gas in the car tire will be greater because the $\Delta U=\frac{3}{2} P V$ or $\Delta U \sim P$. The enlarged gas pressure will break the rubber wall of the car tire that has a fixed maximum $\mathrm{V}$ as a result of which the car tire will explode.

\section{Item question number 6}

Apakah tabung gas yang terisi penuh yang dijatuhkan dari ketinggian tertentu dapat meledak? Jika ya, mengapa demikian!

In the above question, many students have undergone conceptual changes. A total of 28 students who answered because of the influence of pressure exerted on the gas cylinder due to teak from a certain height exceeded the pressure capacity of the gas cylinder 
causing the gas to leak, as a result of which the gas came out at a high speed causing the gas temperature to rise so that it burned. The gas canister did not explode.

Another study that has a relationship with the implementation of process images is research conducted by Rosadi, et al (2015) shows that there are significant differences from the three cycles used mainly in cycle III. In cycle III there has been an increase in the effectiveness of the use of review analysis tasks in the form of process drawings on an environmental event with the results of review on the activeness of student learning, the results of student physics tests and retention of high school physics test results. In addition, Oktavia, et al (2019) also explained that the use of process images in business materials and energy in the form of teaching materials has improved the results of learning physics students with high criteria at meetings. While at the second and third meeting with medium criteria. When viewed from the retention of learning physics using a teaching book based on image-based processes is relatively high. This shows that the implementation of process images on physics has a positive impact on physics learning including changes in concepts that students from this research study.

When associated with learning theory, the implementation of process drawings in the study of the physics of the kinetic theory of gases that are integrated based on real events or phenomena made in a direct and intact manner to get a change in concept is very relevant to the theory of constructivism learning. In applying the theory of constructivism learning can be used constructivism learning model, where this learning model is actually learning based on thinking skills (Pebriyanti at al, 2015). The thinking skill in question is how students can build or structure their ideas to acquire new knowledge in a structured manner based on their experiences (Muijs and Reynold, 2008). So, the process drawings presented in this study can help students to think and discover physical concepts based on the observed images.

\section{CONCLUSION}

Based on the results of the study of conceptual changes in kinetic gas theory material using images of the process provides a noticeable impact of change through an increase with an average increase score of 0.51 (medium gain). This happens because there are still misconceptions experienced by students. Drawings of processes made in the study of kinetic gas theory include Boyle's law, Charles's law, Gay Lussac's law, Boyle's Gay Lussac law, ideal gas equation, ideal gas kinetic energy, ideal gas ekipartition and energy in the ideal gas. Each topic of material is presented the phenomenon of drawing a stage that is direct and intact.

\section{ACKNOWLEDGEMENTS}

Thanks to Dra. Munti'amah as a validator on physics and Siti Musrifa, S.Pd. as waka curriculum man 2 Probolinggo city that provides the opportunity to carry out research in Madrasah.

\section{REFERENCES}

Agustina, M., Yushardi, \& Djoko Lesmono, A. 2018. Analisis Penguasaan KonsepKonsep Teori Kinetik Gas Menggunakan Taksonomi Bloom Berbasis HOTS 
Pada Siswa Kelas XI IPA di MAN Jember. Jurnal Pembelajaran Fisika, Vol. 7 No. 4, Desember 2018, hal 334-340.

Hanna, D., Sutarto, \& Harijanto, A. 2016. Model Pembelajaran Tema Konsep Disertai Media Gambar Pada Pembelajaran Fisika di SMA. Jurnal Pembelajaran Fisika, Vol. 5 No. 1, Juni 2016, hal 23-29.

He, S. 1993. Children's Alternative Frameworks: Should be Directly Addresses in Science Instruction? Jurnal of Research in Science Teahing, 30 (3): 233-248.

Hernawati, E. 2016. Meningkatkan Hasil Belajar Fisika Melalui Penggunaan Metode Demonstrasi dan Media Audiovisual pada Siswa Kelas X MAN 4 JAKARTA. Andragogi Jurnal Diklat Teknis, Volume: VI No. 2.

Muijs, Daniel, dan David Reynols. (2008). Effective Teaching Teori dan Aplikasi. Yogyakarta: Pustaka Belajar.

Oktavia, A. (2019) 'Buku Ajar Berbasis Gambar Proses Dalam Pembelajaran Fisika Seminar Nasional Pendidikan Fisika 2019’, Seminar Nasional Pendidikan Fisika, 4(1), pp. 246-251.

Pebriyanti, D., Sahidu, H., dan Sutrio. (2015). "Efektifitas Model Pembelajaran Perubahan Konseptual Untuk Mengatasi Miskonsepsi Fisika Pada Siswa Kelas X SMAN 1 Praya Barat Tahun Pelajaran 2012/2013", Jurnal Pendidikan Fisika dan Teknologi (ISSN. 2407-6902), Volume I No 1.

Putra, A. P., Rochman, C., \& Setya, W. (2020). PENINGKATAN PENGUASAAN KONSEP FISIKA MENGGUNAKAN LABORATORIUM VIRTUAL PHET MATERI TEORI KINETIK GAS. Journal of Teaching and Learning Physics, 5(2), 80-86.

Rosadi, I. Sutarto, dan Yushardi. (2015). "Tugas Analisis Wacana Dalam Bentuk Gambar Proses Kejadian Lingkungan Pada Pembelajaran Fisika Di SMA”, Jurnal Pembelajaran Fisika, VOL 4 NO 3.

Sutarto, Indrawati, Wicaksono, I. (2018). The Role of Picture of Process (PPO on Senior High School Students' Collisions Concep Learning Activities an MultiRepresentation Ability. IOP Conf. Series: Journal of Physics.

Wicaksono, I.,Sutarto, \& Marzuki, I. 2019. Pengembangan LKM Berbasis MC-GP Menggunakan CAT untuk Melatihkan Kemampuan Berpikir Kritis Mahasiswa. KONSTAN, Volume 4, Nomor 1 Halaman 42-48.

Yaumi, M. R., Sutopo, S., \& Zulaikah, S. (2019). Analisis Penguasaan Konsep dan Kesulitan Siswa pada Materi Teori Kinetik Gas. Jurnal Pendidikan: Teori, Penelitian, dan Pengembangan, 4(10), 1333-1340. 